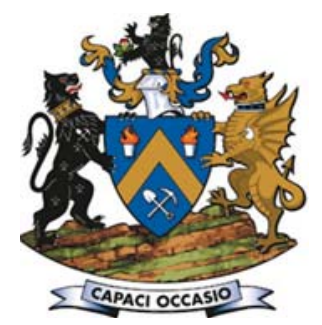

\title{
Impact of thick alluvial soil on a fractured water-conducting zone: an example from Huainan coal mine, China
}

\author{
by D.W. Zhou*, K. Wu* , L. Li*, and J.W. Yu*
}

\section{Synopsis}

The presence of a fractured water-conducting zone (FWCZ) is of significant importance for the safety of underground mining under water bodies. When a coal mining area is covered with a thick layer of alluvial soil, the height, width, and distribution pattern of the FWCZ in the area shows unique features. The internal mechanism by which thick alluvial soil affects the FWCZ is still unknown. Using the Huainan coal mining area (HCMA) in China as a case study, we investigated the impact of thick alluvial soil on the height, width, and distribution pattern of the FWCZ through numerical simulation using the distinct element method, theoretical derivation, and data validation. The results indicate that a thick layer of alluvial soil inhibits the FWCZ height and increases the FWCZ lateral width. When the soil-to-rock ratio is greater than a certain value (the numerical result in this study is 15:18), the FWCZ height and width are affected by the thick alluvium significantly, and the thick alluvial soil alters the shape of the FWCZ from tall and thin to short and wide. The load exerted by the alluvial soil transfers downward to influence the FWCZ; however, this process is obstructed by the hard strata in the bedrock. Therefore, the vertical and lateral change trends show a similar step pattern. Our results can provide a basis for accurate calculation of the FWCZ height in mining areas with thick alluvial soil, to mitigate mine water hazards and increase the safety of underground mining in coal mines covered with a thick alluvium layer. Moreover, reducing the FWCZ height can help extend the upper extraction limit in coal mines covered with a thick alluvium layer, which reduces the thickness of the impermeable coal pillar and increases coal production.

\section{Keywords}

coal mining, thick alluvial soil, fractured water-conducting zone, distinct element method.
2007; Zhang, 2005; Zhang and Shen, 2004; Zhang and Peng, 2005). During extraction from these collieries, water inrushes through fractured water-conducting zones (FWCZs) (Figure 1) into the mining area have caused water disasters (Bai et al., 2013; Bureau et al., 1983; Chen et al., 2013; Guo et al., 2008; He et al., 1991; Industry, 2004; Li and Zhou, 2005; Peng and Zhang, 2007; Peng, 1992; Wang and Park, 2003; Yang et al., 1994; Yuan and $\mathrm{Wu}, 2003$; Yuan et al., 2001; Zhang, 2005; Zhang and Shen, 2004; Zhang and Peng, 2005; Zhang et al., 2002). In some cases, the consequences were catastrophic, leading to partial or even total loss of the mine (Bai et al., 2013; Islam et al., 2009; Li et al., 2013; Peng and Zhang, 2007; Wu et al., 2011, 2015; Yang et al., 2007).

It is well known that, after sufficient extraction of a longwall panel, the original stress balance of the rock mass overlying the stope is disturbed and the overburden strata undergo various degrees of movement, causing subsidence and caving of the overlying rock mass. According to their movement characteristics, the fractured overburden strata can be divided into four zones from bottom to top: the caving zone, fractured zone (or fault zone), bending zone, and alluvial soil zone, as shown in Figure 1 (Brady and Brown, 2004; He et al., 1991; Industry, 2004; Kratzsch, 1983; Miao et al., 2011; Peng and Zhang, 2007; Peng, 1992; Qian et al., 2003, 2010; Qian, 1982; Yuan and $\mathrm{Wu}, 2003)$ :

China, supplies approximately $70 \%$ of the national energyrequirement. However, many coal mines in China are threatened by water bodies such as rivers, lakes, reservoirs, and groundwater during coal extraction. Approximately 125 rivers flow through China's coalfields, and more than 200 coal mines are confronted with problems of mining under rivers (Miao et al., 2011; Peng and Zhang, 2007). According to incomplete official statistics, there are 600 major coal mines in China, approximately 285 of which are threatened by water inrushes during mining operations. The total coal reserves threatened by bodies of water are estimated at $2.5 \times$ 1010 t (Miao et al., 2011; Peng and Zhang,
> Caving zone (immediate roof)-After coal extraction, the immediate roof strata cave irregularly and fall into the void.

\footnotetext{
* School of Environment Science and Spatial Informatics, China University of Mining and Technology, Xuzhou, China.

(C) The Southern African Institute of Mining and Metallurgy, 2016. ISSN 2225-6253. Paper received Dec. 2014; revised paper received Oct. 2015.
} 


\section{Impact of thick alluvial soil on a fractured water-conducting zone}

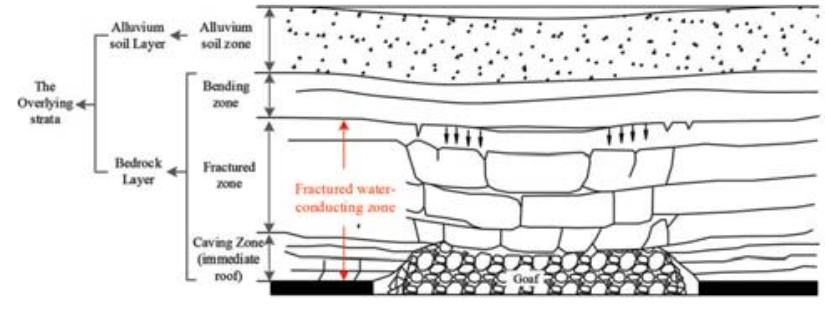

Figure 1-Cross-section of four zones of strata movement above a longwall goaf

The caved strata behave not only completely as a discontinuity, but also irregularly. The caving zone is normally 2-8 times the mining height, depending on the properties of the immediate roof strata

> Fractured zone-Stratum breakage and discontinuity are the basic characteristics in this zone, while the rock retains its stratified bedding. The stratum breakage gradually decreases upwards, resulting in a decrease in the fracture network development and, of course, the permeability of the stratum. The combined height of the fractured and caving zones is approximately 20-30 times the mining height in hard or strong rock, 12-15 times in medium-hard rock, and 9-11 times in soft or weak rock

> Bending zone-The strata above the fractured zone deflect downward without apparent breakage. The continuity of the strata and the original stratified features remain. In some cases, impermeability is temporarily lost but regained soon afterwards. Some opening fissures may appear in the tension zone but in general the strata maintain continuity

> Alluvial soil zone-This zone is the surface layer (also called the Quaternary alluvium layer), and its thickness depends on the location. In China, the coal-mining areas with a Quaternary alluvium layer less than $50 \mathrm{~m}$ thick are called thin alluvium mining areas and are the most common. Coal mining areas with an alluvium layer more than 100-300 m thick are known as thick alluvium mining areas, while areas with an alluvium layer more than $300 \mathrm{~m}$ thick are known as mega-thick alluvium mining areas. The areas with thick alluvium are widely distributed in China, mainly in Huaibei, Huainan, Yanzhou, Datun, Jiaozuo, Pingdingshan, Yongxia, Kailuan, Xingtai, and other mining areas of east, central, north, and northeast China (He et al., 1991; Industry, 2004; Liu et al., 2012; Zhou, 2014; Zhou et al., 2015). Depending on the physical properties of the soils, cracks may open in the area around the working face and close again after the mining extraction face advances further. However, some cracks, especially those along the edges of the mining panel, may remain open after the mining face has moved on, but the fracture walls tend to collapse and fill in the cracks.

As shown in Figure 1, the caving zone and the fractured zone are jointly termed the FWCZ, and the bending zone and the FWCZ are jointly called the bedrock layer. The entire range of overlying strata includes the bedrock layer and the alluvial soil. When mining under water bodies, the FWCZ is critically important, providing access for water inflow into the mine workings due to the increased hydraulic conductivity in this zone.

In safe mining practice, an impermeable coal pillar is usually left in place to prevent groundwater or surface water from flowing into mining workings through the mininginduced fractured zone (He et al., 1991; Industry, 2004; Peng and Zhang, 2007; Peng, 1992; Yuan and Wu, 2003; Zhang, 2005; Zhang and Shen, 2004; Zhang and Peng, 2005; Zhang et al., 2002). The impermeable pillar enables successful seam extraction with neither water inrush nor excessive groundwater discharge into the mine. This practice requires that the fractured zone does not penetrate upwards into the overlying aquifers. Normally, the minimum height of the impermeable pillar must be not less than the maximum height of the fractured zone plus the height of a protective layer (He et al., 1991; Industry, 2004; Peng and Zhang, 2007).

$$
H_{w} \geq H_{f}+H_{p}
$$

where $H_{w}$ is the vertical height of the impermeable pillar, $H_{f}$ is the maximum vertical height of the fractured zone, and $H_{p}$ is the height of the protective layer. For example, the thickness of the impermeable coal pillar in the south mining area of the Huainan coal mining area (HCMA) under common geological conditions is $80 \mathrm{~m}$ (Bureau et al., 1983; Wang, 1999; Yuan and Wu, 2003; Zhang et al., 2002). Therefore, a large amount of coal contained in the impermeable coal pillar cannot be extracted, which represents a loss of coal resources.

Due to the importance of the FWCZ, there has been much interest in studies of the FWCZ in mining research (Bureau et al., 1983; Gui et al., 1997; He et al., 1991; Industry, 2004; Lu and Wang, 2015; Ma et al., 2013; Miao et al., 2011; Peng and Zhang, 2007; Peng, 1992; Qian et al., 2003, 2010; Teng, 2011; Tu, 2004; Wang et al., 2003; Wu et al., 2008; Xu et al., 2010; Yang and Gao, 1982; Yuan and Wu, 2003; Yuan et al., 2015; Zhang, 2005; Zhang and Shen, 2004; Zhang and Peng, 2005). These studies show that the main factors influencing the height and distribution pattern of the FWCZ are the lithology of the strata, the coal mining method, and the thickness of the overlying strata. According to recent data for the height of the FWCZ in thick -alluvium coal mining areas, the height, width, and distribution pattern of the mining-induced FWCZ in these areas differs from those in thin alluvium coal mining areas. Therefore, the influence of thick alluvial soil on the FWCZ must be taken into account. Based on the measured data for a longwall panel in the Yanzhou mining area, where fully mechanized mining was taking place, Teng (2011) found that the thick alluvial soil layer inhibited the height of the FWCZ. We found a similar phenomenon when analysing data from the FWCZ of the HCMA. Although this phenomenon has been recorded, the process and internal mechanism are unknown and need to be investigated. Despite recent studies on the FWCZ, a number of issues remain unresolved:

> Current research is focused more on calculation and prediction of the height than on the width of the FWCZ. However, the lateral extent of the zone is related to the inrushing of water from the old goaf adjacent to the mining area 


\section{Impact of thick alluvial soil on a fractured water-conducting zone}

Research on the FWCZ in thick alluvium coal mining areas is relatively sparse, especially studies on the impact of thick alluvial soil on the FWCZ.

Using the Huainan mining areas as a case study, this paper investigates the impact of thick alluvial soil on the height, width, and distribution pattern of the FWCZ through numerical simulation, theoretical derivation, and validation with measured data, while providing a reference for an accurate calculation of the FWCZ height. Our results can be used by engineers and mining personnel to increase the safety of underground mining and to reduce the size of the impermeable coal pillars in order to increase the extraction of coal and boost production.

\section{Geological and mining conditions of HCMA}

The HCMA near the Huaihe River, China is divided into two mining areas; the 'South Area' and the 'North Area'. The layout of the mining areas is shown in Figure 2. As the two areas are part of the same coalfield, their lithologies are basically the same (Yang et al., 1994; Yuan and Wu, 2003; Zhou, 2014; Zhou et al., 2015). The main difference between the two areas is the thickness of the Quaternary alluvial soil layer; the thickness in the North Area is 160-500 m, while that in the South Area is only $20-40 \mathrm{~m}$. This difference in the alluvial soil layer thickness provides favourable conditions for research into the impact of the layer thickness on the FWCZ.

The coal-bearing strata of the HCMA belong to the Carboniferous-Upper Permian Taiyuan Group and the Permian Lower Shanxi Group and Shihezi Group. There are 8-10 mineable coal seams in the stratum; the seams are relatively regular, and the dip is nearly flat in the North Area. The geological structure is complex; the mining depth is 500$900 \mathrm{~m}$ in the North Area, and the bedrock is covered with thick alluvial soil. The mining depth in the South Area is around $300 \mathrm{~m}$. The lithology of the coal-seam roof and floor is mainly mudstone, sandy mudstone, and sandstone, of medium hardness (Yuan and Wu, 2003; Zhou, 2014; Zhou et al., 2015).

\section{Numerical simulation and related parameters}

The Universal Distinct Element Code (UDEC) is a twodimensional numerical program based on the distinct element method for discontinuous modeling (Cundall, 1988; ITASCA Consulting Group, 2004; Hart et al., 1988; Jing, 2003) and is frequently used in rock mechanics (ITASCA Consulting Group, 2004; Moarefvand and Verdel, 2008). It is particularly suited for analysing fractured masses and large displacements along discontinuities (Cundall, 1988, 1990; ITASCA Consulting Group, 2004; Hart et al., 1988; Jing, 2003; Moarefvand and Verdel, 2008; Xu and Zhang, 2002). We used UDEC4.0 for the numerical simulations in this study.

A numerical model was established for simulating a working face in HCMA with measured geological conditions. The thickness of the coal seam in the working face is $4 \mathrm{~m}$ on average, the average dip angle is nearly flat, and the working face is a longwall panel face with bedrock layer thickness of approximately $180 \mathrm{~m}$ covered by $400 \mathrm{~m}$ of alluvial soil (the total thickness of the overlying strata is approximately $580 \mathrm{~m}$ ). The length of the working face is approximately $800 \mathrm{~m}$ and the width approximately $120 \mathrm{~m}$. Fully mechanized coal-mining technology is employed, and the roof is managed with longwall full caving.

According to the geo-mining conditions, the length of the model is $1200 \mathrm{~m}$; the goaf runs along the coal seam with a length of $800 \mathrm{~m}$ (along the length of the working face), starting at $200 \mathrm{~m}$ from the left edge and extending to $1000 \mathrm{~m}$ from the left edge of the model; and the mining height is $4 \mathrm{~m}$. The interval of mining is approximately $80 \mathrm{~m}$. The open-off cut is located at the left of the model and the terminal line is at the right (Figure 3).

In the model, the bedrock thickness was fixed at $180 \mathrm{~m}$, and the coal seam was nearly horizontal. Ten models were constructed with alluvial soil thicknesses of $0,50,100,150$, $200,250,350,400$, and $450 \mathrm{~m}$. The models are based on the Mohr-Coulomb criterion. The main physical parameters of the bedrock layers in the model are shown in Table I. These parameters were obtained by field observations in HCMA. The left and right boundaries of the model have a single constraint, the lower boundary is fully constrained, and the upper boundary is free. The horizontal observation lines are spaced at $5 \mathrm{~m}$ intervals in the strata above the coal seam, and the interval between the observation points on the observation lines is $10 \mathrm{~m}$.

\section{Criteria determination for the FWCZ}

\section{FWCZ height}

Based on the type of damage in the overlying rock caused by the coal mining, the strata can be divided into five zones

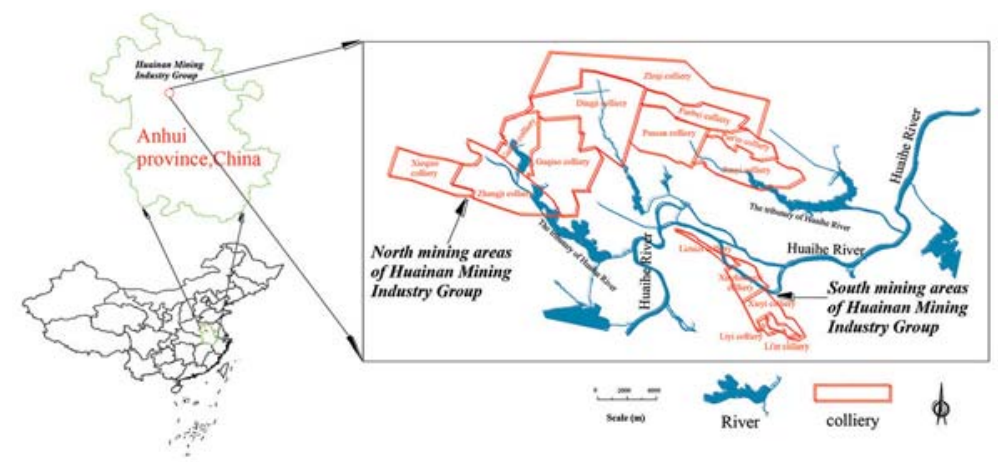




\section{Impact of thick alluvial soil on a fractured water-conducting zone}

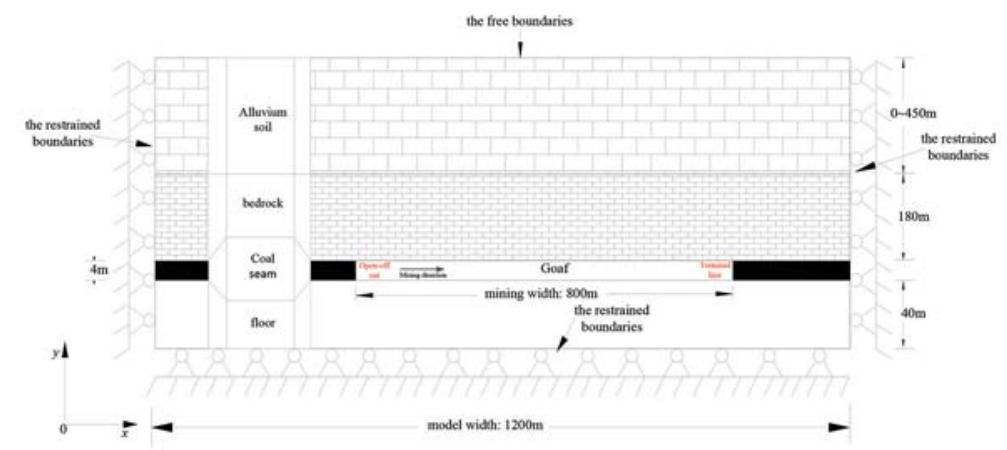

Figure 3-Schematic section of the calculation model

Table I

The main physical parameters of the bedrock layers in the model

\begin{tabular}{|c|c|c|c|c|c|c|c|c|c|}
\hline No. & Lithology & $\begin{array}{c}\text { Tensile } \\
\text { strength (MPa) }\end{array}$ & $\begin{array}{c}\text { Elasticity } \\
\text { modulus (GPa) }\end{array}$ & $\begin{array}{l}\text { Cohesion } \\
\text { (MPa) }\end{array}$ & $\begin{array}{c}\text { Internal friction } \\
\text { angle }\left({ }^{\circ}\right)\end{array}$ & $\begin{array}{l}\text { Density } \\
\text { (kg.m-3) }\end{array}$ & $\begin{array}{l}\text { Poisson's } \\
\text { ratio }\end{array}$ & $\begin{array}{l}\text { Normal stiffness } \\
\text { coefficient (GPa) }\end{array}$ & $\begin{array}{l}\text { Shear stiffness } \\
\text { coefficient (GPa) }\end{array}$ \\
\hline 1 & Alluvial soil & 0.05 & 1.50 & 0.074 & 24 & 2000 & 0.29 & 0.5 & 0.3 \\
\hline 2 & Siltstone & 1.60 & 1.60 & 4.50 & 28 & 2570 & 0.25 & 10 & 8 \\
\hline 3 & Quartz sandstone & 2.30 & 3.73 & 11.00 & 41 & 2730 & 0.24 & 10 & 8 \\
\hline 4 & Sandy mudstone & 1.60 & 2.00 & 2.50 & 33 & 2530 & 0.22 & 10 & 8 \\
\hline 5 & Mudstone & 1.26 & 1.80 & 2.32 & 27 & 2520 & 0.26 & 10 & 8 \\
\hline 6 & Medium sandstone & 5.03 & 3.10 & 10.10 & 37 & 2600 & 0.23 & 10 & 8 \\
\hline 7 & Siltstone & 2.02 & 2.60 & 2.80 & 32 & 2570 & 0.21 & 10 & 8 \\
\hline 8 & Argillaceous siltstone & 1.80 & 2.50 & 5.66 & 30 & 2500 & 0.16 & 6 & 4 \\
\hline 9 & Silty fine sand & 5.80 & 2.70 & 2.20 & 35 & 2500 & 0.202 & 6 & 4 \\
\hline 10 & Mudstone & 1.43 & 1.95 & 1.68 & 27 & 2520 & 0.15 & 6 & 4 \\
\hline 11 & Sandy mudstone & 2.70 & 2.40 & 2.50 & 32 & 2500 & 0.20 & 6 & 4 \\
\hline 12 & Coal & 1.10 & 1.20 & 0.80 & 20 & 1400 & 0.23 & 0.8 & 0.4 \\
\hline 13 & Medium sandstone & 5.14 & 2.20 & 8.50 & 40 & 2600 & 0.134 & 6 & 4 \\
\hline 14 & Silty fine sand rock & 3.12 & 1.50 & 5.50 & 33 & 2550 & 0.14 & 6 & 4 \\
\hline
\end{tabular}

(Figure 4). The characteristics of the five sections are as follows (Cui et al., 2000; Gui et al., 1997; Huang et al., 2006; Kirsten and Stacey, 1989; Wu et al., 2008):

> Area I (undamaged area) - the elastic zone where the rock mass is not damaged

> Area II (plastic deformation area)—strong rock suffers plastic deformation, and brittle rock is subject to shear failure

> Area III (tensile fracture zone) - tensile stress in a certain direction exceeds the tensile strength of the rock mass and generates tension cracks in this direction

> Area IV (tensile damage zone) - under the influence of two-way tensile stress, the stratum breaks, resulting in a large deformation, identified as the caving zone

$>$ Area $V$ (fractured zone in the local tension zone)because the overburden rock subsides above the goaf, local fractures occur under the action of tensile stress on the edge of the subsidence basin.

Based on the analysis above, we determine the criterion for the FWCZ height as follows: the FWCZ extends vertically from the upper boundary of the tensile fracture zone to the upper boundary of the tensile damage zone.

\section{Lateral width of FWCZ}

After coal mining, the original internal stress of the rock mass is disrupted and the stress is redistributed. Stress is concentrated in the abutment rock surrounding the goaf, causing plastic deformation. Based on the stress and deformation distribution, we can identify four areas that are formed, from the goaf boundary through the surrounding rock (Liu, 2008; Qian et al., 2010; Yuan and Chen, 1986): (A) the fractured zone, (B) the plastic zone, (C) the elastic zone, and (D) the original stress zone. The distribution and stress variation characteristics of the four deformation zones are shown in Figure 5. The strength of the rock mass in the fractured zone is significantly reduced, becoming lower than the original stress $\mathrm{rH}$ and leaving only a residual strength to support the external load. This leads to fracturing of the rock

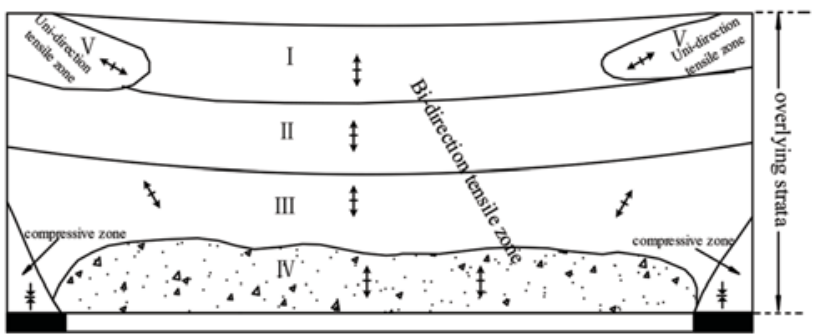

Figure 4-Principal stress distribution and destruction zones in overlying strata after mining (Gui et al., 1997) 


\section{Impact of thick alluvial soil on a fractured water-conducting zone}

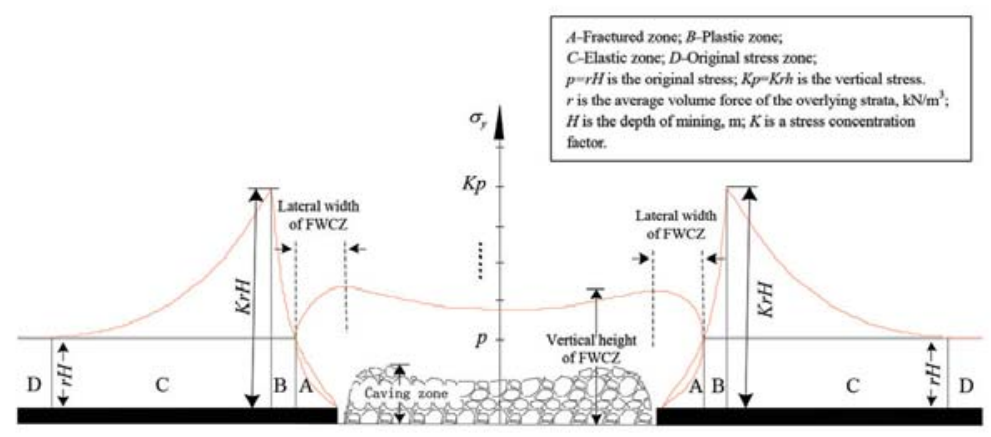

Figure 5-Vertical stress and deformation distribution of the mined-out area
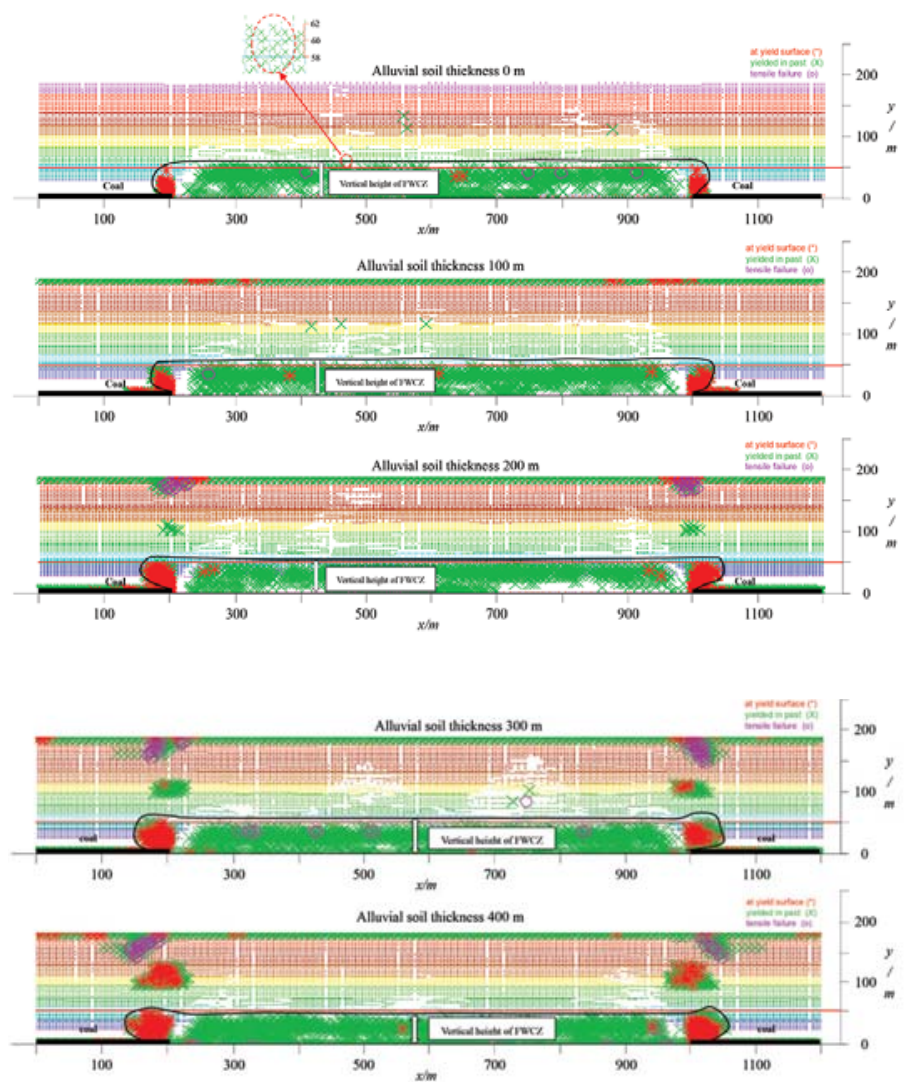

Figure 6-Diagrams of deformation distribution in the FWCZ after mining (mining scope is from $200 \mathrm{~m}$ to $1000 \mathrm{~m}$ )

mass and displacement in the 'stress-reducing area'. The internal stresses in the plastic and elastic zones are higher than the original stress; hence these zones are known as the 'increased stress area'.

Based on the analysis above, we determine the boundaries on both sides of the fracture zone as the width boundaries of the FWCZ (Figure 5).

\section{Simulation results and discussion}

\section{Effects on the height of the FWCZ}

The distribution of deformation in the FWCZ after mining with various alluvium thicknesses is shown in Figure 6. Based on the criteria for determining the FWCZ height, the heights for different alluvium thicknesses can be obtained, as shown in Table II. The vertical height in the models is measured by first determining the distribution zone of deformation, and then counting the grids, because the distance between grids is fixed.

Note: The vertical heights of the FWCZ shown in Figure 6 are quite close to each other (refer to the Table II); in order to express the results more clearly, we present the data in Figure 6 at intervals of $100 \mathrm{~m}$ thickness of the alluvium layer.

We define the ratio of alluvial soil thickness to the thickness of bedrock layer as the soil-to-rock ratio and use it as a standard to evaluate the effect of the alluvial soil on the FWCZ. Table II presents the FWCZ heights for different values of alluvial soil thickness. The relationship between the FWCZ height and the soil-to-rock ratio is shown in Figure 7. 


\section{Impact of thick alluvial soil on a fractured water-conducting zone}

From the simulation results, we can draw the following conclusions:

$>$ From the overall trend, as the thickness of the alluvial soil layer increases, the height of the FWCZ is reduced to a certain level, which reflects the inhibition of the FWCZ height by the thick alluvium layer. According to

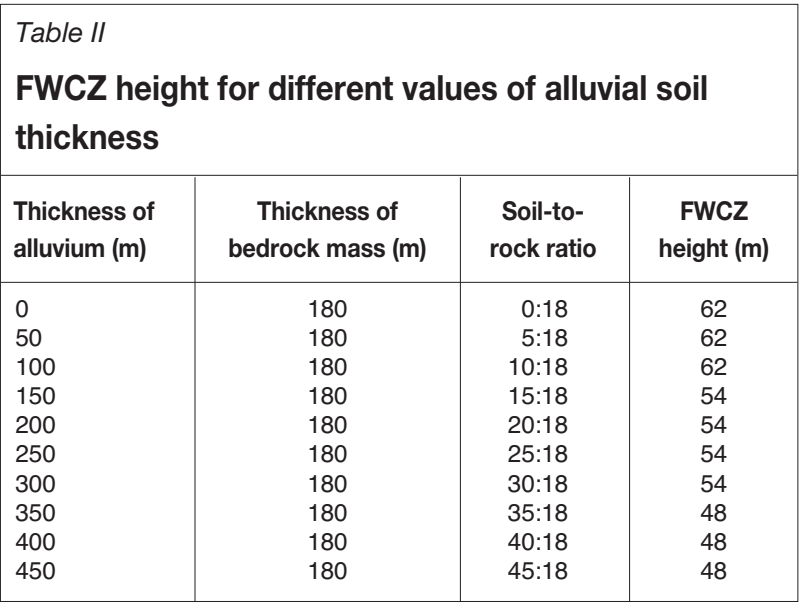

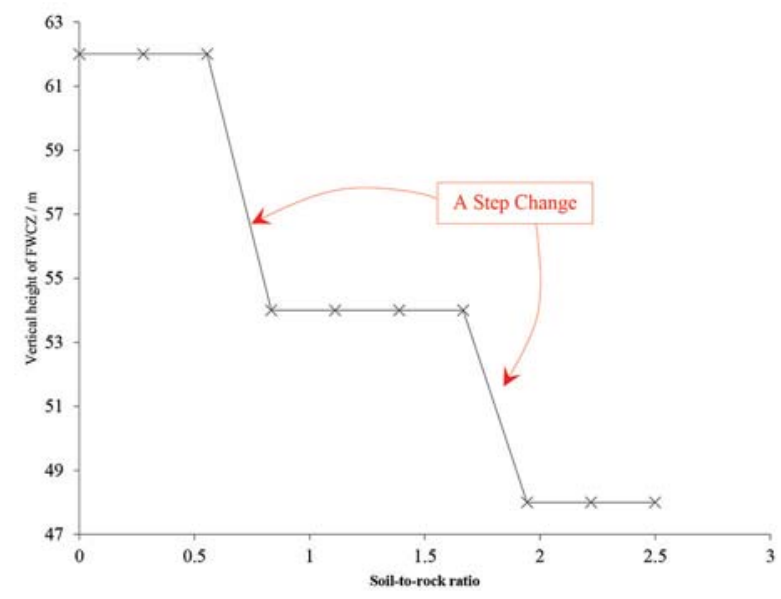

Figure 7-Relationship between the vertical height of the FWCZ and the soil-to-rock ratio the results of the simulations, when the soil-to-rock ratio is less than 10:18, the height of the FWCZ does not change significantly. When the ratio is greater than $15: 18$, the FWCZ height is considerably affected by the thick alluvium

> Through numerical simulation and theoretical analysis, we observe that when the alluvium is thick enough, it will transfer a load down to the goaf; as the alluvium thickness increases, the stress in the bedrock and goaf increases and the broken rock mass inside the caving zone in the goaf is increasingly compacted under the alluvium load. The expansion of broken rock decreases, and the fracturing and bed separation within the fracture zone become more packed, thus inhibiting the development of the FWCZ vertically

- Figure 7 and Table II show that the reduction in FWCZ height is stepped and not continuous. The main reason for this is that the process of transferring the thick alluvium load is related to the lithology of the strata, that is, it is impacted by the hard rock layer, i.e. the key stratum (Qian et al., 2003; Qian, 1982). When the soilto-rock ratio reaches $15: 18$, the effect of the first hard stratum (stratum 6 in Table I) is attenuated and the alluvium load is transmitted downward, which affects the development of the FWCZ height. When the ratio reaches $35: 18$, the alluvium load will break through the second hard rock stratum (stratum 9 in Table I), and the load will be transmitted down to the goaf, resulting in further reduction of the FWCZ height. However, the underground goaf space is limited ( $4 \mathrm{~m}$ goaf width) and the rock fracture and separation zone is limited; therefore the height of the FWCZ does not decrease indefinitely, but tends to gradually stabilize.

\section{Effects on the width of the FWCZ}

The vertical stresses in the roof strata and fracture zone are shown in Figure 8. Note that here, too, we present the data at $100 \mathrm{~m}$ intervals of the alluvium layer thickness in Figure 8; if it were drawn at $50 \mathrm{~m}$ intervals, Figure 8 would be too crowded be clearly understood. Table III provides statistics of the FWCZ width. The relationship between the width and the soil-to-rock ratio is shown in Figure 9.

From the simulation results, we can draw the following conclusions:

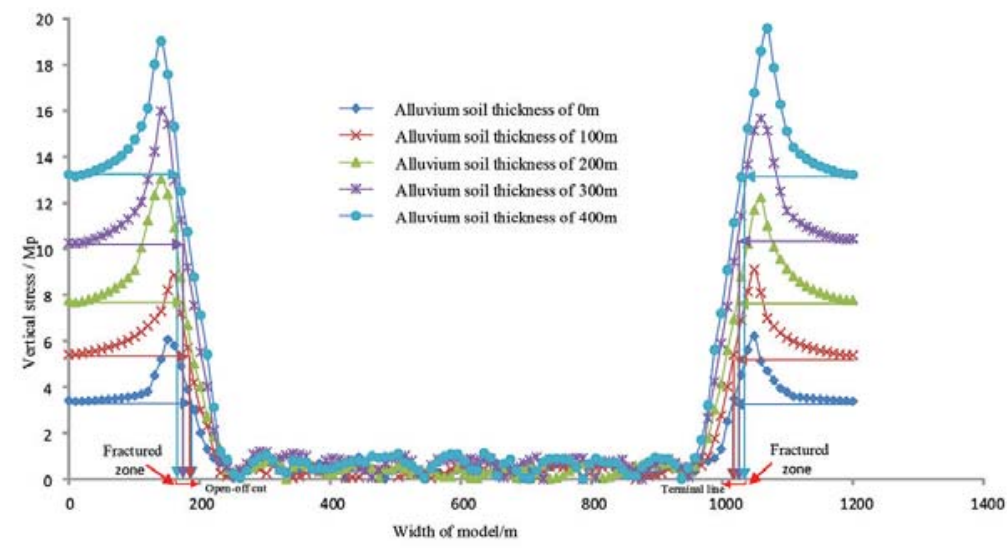

Figure 8-Roof vertical stress and coal stratum fractured zone distribution (mining scope of coal seam is 200-1000 m) 


\section{Impact of thick alluvial soil on a fractured water-conducting zone}

The width of the FWCZ increases with the alluvium thickness. In the process of coal mining, the area above the goaf is the unloading area while the area above the two sides of the coal pillar is an area of stress concentration. Under the effect of compressive stress, plastic deformation occurs on both sides of the rock mass; with increased alluvial soil thickness, the compressive stress at the top of the coal pillar rises and the width of the FWCZ increases

> Since the alluvium load is affected by lithology as it spreads down through the strata, the trends for width

\begin{tabular}{|c|c|c|c|}
\hline \multicolumn{4}{|l|}{ Table III } \\
\hline \multicolumn{4}{|c|}{$\begin{array}{l}\text { Lateral width of the FWCZ for different alluvium } \\
\text { thickness }\end{array}$} \\
\hline $\begin{array}{l}\text { Thickness of } \\
\text { alluvium }(\mathrm{m})\end{array}$ & $\begin{array}{c}\text { Thickness of } \\
\text { bedrock mass (m) }\end{array}$ & $\begin{array}{c}\text { Soil-to- } \\
\text { rock ratio }\end{array}$ & $\begin{array}{l}\text { Lateral width of } \\
\text { the FWCZ (m) }\end{array}$ \\
\hline 0 & 180 & $0: 18$ & 12 \\
\hline 50 & 180 & $5: 18$ & 12 \\
\hline 100 & 180 & $10: 18$ & 13 \\
\hline 150 & 180 & $15: 18$ & 22 \\
\hline 200 & 180 & $20: 18$ & 22 \\
\hline 250 & 180 & $25: 18$ & 22 \\
\hline 300 & 180 & $30: 18$ & 22 \\
\hline 350 & 180 & $35: 18$ & 30 \\
\hline 400 & 180 & $40: 18$ & 32 \\
\hline 450 & 180 & $45: 18$ & $32 a$ \\
\hline
\end{tabular}

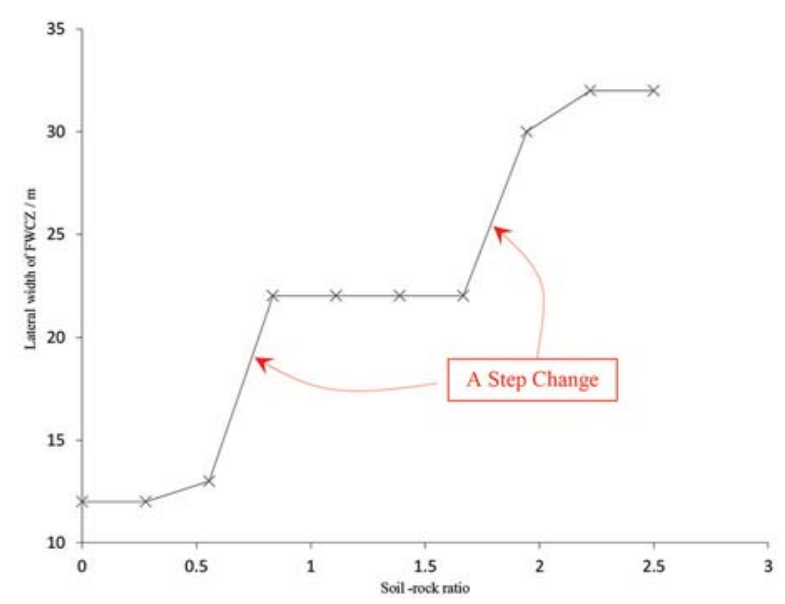

Figure 9-Relationship between the lateral width of the FWCZ and the soil-to-rock ratio are similar to those for height, also showing step changes. Because the bearing capacity of hard rock is quite high, the alluvium load at the initial stage (where the soil-to-rock ratio is less than 15:18) has a smaller effect on the goaf. When the soil-to-rock ratio reaches 15:18, because the rock mass has a strain-softening characteristic (Liu, 2008; Qian et al., 2010; Yuan and Chen, 1986), the alluvium load reaches or becomes greater than the threshold load level of the first layer of hard rock and the strength of the rock mass itself is attenuated. The load is then transmitted down, and the FWCZ width increases from $12 \mathrm{~m}$ to $22 \mathrm{~m}$. When the soil-to-rock ratio reaches $35: 18$, the strength of the second layer of hard rock is attenuated and the lateral width increases from $30 \mathrm{~m}$ to $32 \mathrm{~m}$. Therefore, the FWCZ in thick alluvium mining areas is more likely to intersect the FWCZ in the adjacent old goaf at the lateral boundary, which can lead to water flowing from the old goaf into the mining area (Xu et al., 2010).

\section{Comprehensive analysis}

According to the simulation results, under the influence of a thick alluvium layer, the FWCZ height decreases and its width increases. Figure 10 shows the effect of alluvial soil thickness on the height and width of the FWCZ and its distribution pattern. The following patterns can be observed.

> When the alluvium is thick enough (soil-to-rock ratio in simulation > 15:18), the load of the thick alluvium layer is transferred to the strata below, affecting the fractured rock mass and bed separation in the goaf. This affects the height, width, and distribution pattern of the FWCZ. An alluvium layer of a certain thickness will inhibit the height and increase the width of the FWCZ, as shown in Figure 10a-c. The FWCZ changes from a tall and narrow shape (Figure 10a) to a short and wide shape (Figure 10c)

> The thick alluvial soil loads the goaf, compacting the fractured rock mass in the goaf and causing the bed separation to become more closely packed. The displaced space in the rock mass is transferred to the surface in the form of subsidence.

\section{Validation using measured data}

\section{Borehole method for validation of FWCZ height}

In the HCMA, the height of the FWCZ in the overlying strata during coal mining is ascertained mainly by drilling boreholes from the surface to the rock strata and flushing the

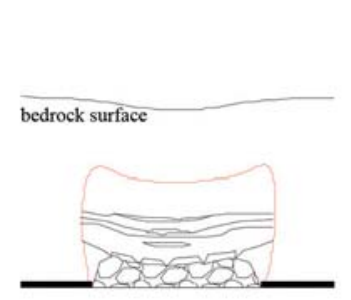

(a) Non-alluvium deposit (or thin alluvium)

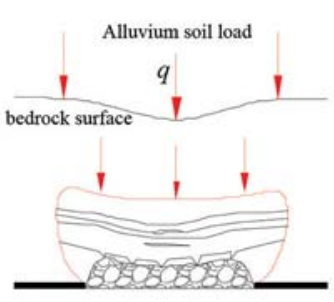

(b) Thick alluvium

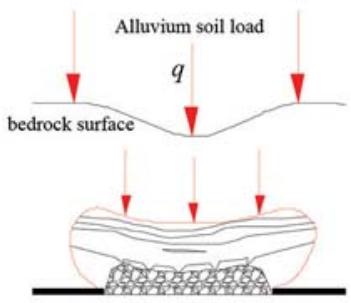

(c) Mega-thick alluvium

Figure 10-Effect of alluvial soil thickness on the height and width of the FWCZ and its distribution pattern 


\section{Impact of thick alluvial soil on a fractured water-conducting zone}

boreholes with liquid (Luo, 1982; Miao et al., 2011; Yang and Gao, 1982). The permeability of the rock mass is determined mainly by the amount of absorbed liquid. Inside the FWCZ, the fracture growth increases from top to bottom and the permeability is also enhanced. The water flow leading to the fracture can be discharged by permeating through the rock mass to the goaf, but cannot be stored in this zone. The water diffuses and flows vertically inside this zone, unlike the radial flow of groundwater in aquifers. Due to this phenomenon, boreholes have the following characteristics after entering the FWCZ from the top interface of the overlying strata:

> Leakage of flushing liquid, where the amount of leakage increases with the drilling depth. After the feed stops, the water level of the borehole drops to the bottom of the hole

> Suction phenomena occur, that is, when the drill is at the bottom of the hole, the pump stops, the steel ball inside the pump bounces, and the borehole begins to draw down water. The amount of water that is drawn down is subject to the pipe impermeability, depth of drilling, and other factors

- After drilling to a certain depth, the penetration rate increases; voids and cross-holes can occur regularly.

Based on the above characteristics, we can determine when the borehole has entered the top interface of the FWCZ. Figure 11 presents the layout of observation boreholes and the development of the FWCZ.

\section{Analysis of measured data}

In this study, 15 data-points were measured for the height of FWCZs in the North Area and South Area of the HCMA. Figures 12 and 13 compare the heights of the FWCZ in the
North Area and South Area with different coal mining methods.

Figure 12 shows the measured height of the FWCZ in nine boreholes in the North Area and South Area under conditions of drill-and-blast mining. The average height is $29.2 \mathrm{~m}$ in the North Area and $32.5 \mathrm{~m}$ in the South Area.

Figure 13 shows the measured height of the FWCZ in four boreholes in the North Area and South Area under conditions of fully mechanized mining. The average height is $40.6 \mathrm{~m}$ in the North Area and $45.6 \mathrm{~m}$ in South Area.

The most significant difference between the North Area and South Area is the thickness of the alluvial soil (the North Area is a thick alluvium mining area and the South Area is a thin alluvium mining area). According to the measured data, the FWCZ height in the North Area is lower than in the South Area: approximately $11.3 \%$ lower under drill-and-blast

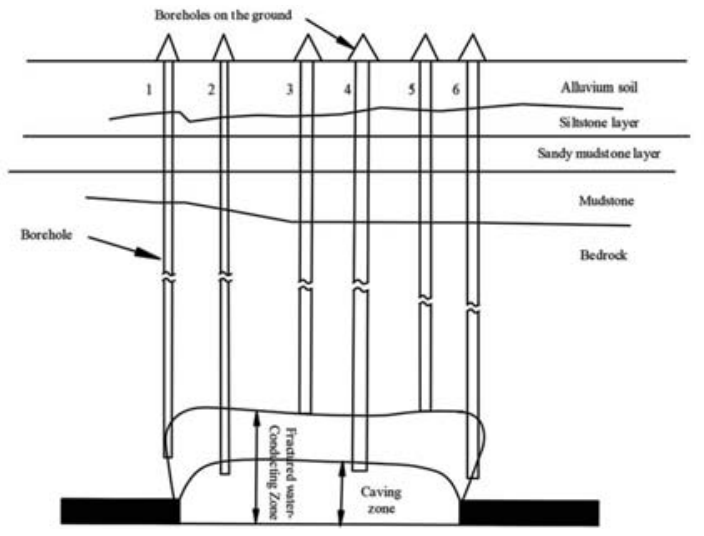

Figure 11-Layout of observation boreholes and development of the FWCZ
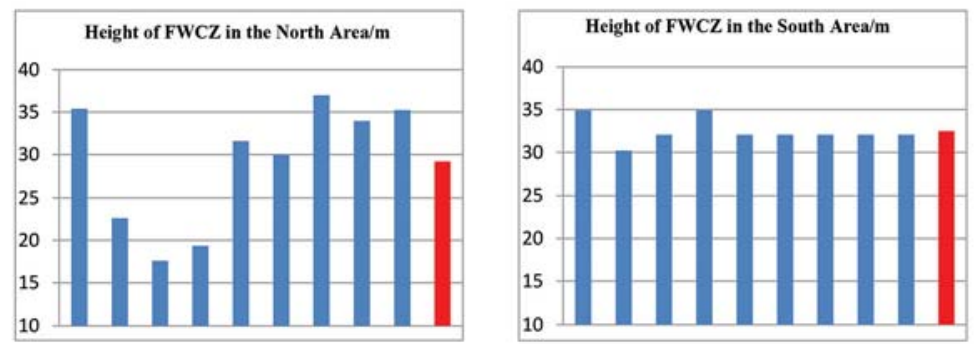

Figure 12-Comparison of measured FWCZ heights in the North Area and South Area of HCMA under longwall blasting mining. The red column represents the average of the nine data-points (soil-to-rock ratio 1.6-4.7)
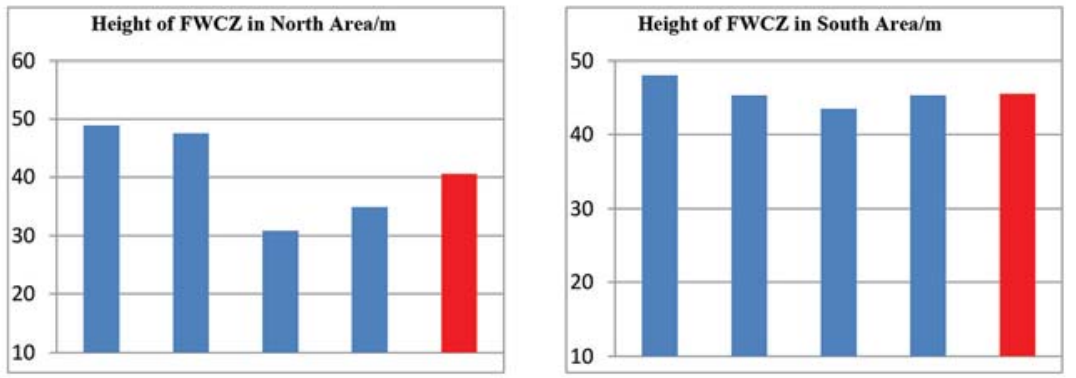

Figure 13-Comparison of measured FWCZ heights in North Area and South Area of HCMA under longwall fully-mechanized coal mining. The red column represents the average of the four data points (soil-to-rock ratio 1.6-4.7) 


\section{Impact of thick alluvial soil on a fractured water-conducting zone}

mining conditions and $12.3 \%$ lower under fully mechanized mining conditions. This indicates that the thick alluvium layer in the North Area has an inhibitory effect on the height of the FWCZ, which agrees with the simulation results.

The reduction in FWCZ height is helpful for extending the upper extraction limit in coal mines covered with a thick layer of alluvial soil and reducing the thickness of the impermeable coal pillar. For example, the upper extraction limit for the North Area of the HCMA can be extended up by $12.3 \%$ under fully mechanized mining conditions. As stated above, the thickness of the impermeable coal pillar in the South Area of HCMA is $80 \mathrm{~m}$. Therefore, the thickness of the impermeable coal pillar in the North Area of HCMA can be reduced by $12.3 \%$, which allows an additional $9.8 \mathrm{~m}$ of coal seam thickness to be extracted, greatly increasing coal production.

\section{Conclusions}

The following major conclusions can be drawn from this study.

> According to the results of the numerical simulation and measured data, a certain thickness of alluvial soil layer inhibits the height of the FWCZ. When the soilto-rock ratio is greater than a certain value (the value in the numerical simulation of this paper is $15: 18$ ), this can significantly affect the vertical height of the FWCZ. Moreover, an alluvium layer of a certain thickness increases the width of the FWCZ. Under the influence of thick alluvium, the overall shape of the FWCZ changes from long and thin to short and wide

- The internal mechanism of the impact of thick alluvium on the FWCZ is as follows. The load from the thick alluvium spreads to the underlying rock mass, affecting the fractured rock mass above the goaf and the bed separation in the goaf. This affects the height, width, and distribution pattern of the FWCZ. When the thickness of alluvium increases, the fractured rock mass in the caving zone in the goaf is more compressed under the alluvium load, and the expansion of the broken rock decreases; the fracturing and bed separation inside the fractured zone tends to become more closely packed, thus inhibiting and reducing the height of the FWCZ. However, the space in the broken rock mass, fractured areas, and bed separation is limited. The reduction in FWCZ height is helpful for extending the upper extraction limit in coal mines covered with a thick layer of alluvial soil and reducing the thickness of the impermeable coal pillar, which greatly increases coal production.

\section{Acknowledgements}

The research was financially supported by the Priority Academic Program Development of the Jiangsu Higher Education Institutions (PAPD), Natural Science Foundation of Jiangsu Province under Grant No. BK20150187, the National Technology Support Programs of China during the Twelfth Five-Year Plan Period under Grant No. 2012BAC04B03, and The Scientific Research Foundation of the Jiangsu Key Laboratory of Resources and Environmental Information Engineering (China University of Mining and Technology), approval number JS201109. All these sources are gratefully acknowledged. We thank Professor Axel Preusse and his PhD student Markus Papst from RWTH Aachen University for improving the English of the paper. The authors are also deeply grateful to the anonymous reviewers for their very constructive criticism and suggestions, which led to the improvement of the paper.

\section{References}

BAI, H., MA, D., and CHEN, Z. 2013. Mechanical behavior of groundwater seepage in karst collapse pillars. Engineering Geology, vol. 164. pp. 101--106.

BRADY, B.H.G. and Brown, E.T. 2004. Rock Mechanics For Underground Mining. Springer, New York.

BuREau, H.C.M., Mine, L.T.Z.C., and Branch, T.C. 1983, Mining under the Huaihe River and its embankment. Mine Surveying, no. 1. pp. 26-33 (in Chinese).

Chen, L., Zhang, S., and Gui, H. 2013. Prevention of water and quicksand inrush during extracting contiguous coal seams under the lowermost aquifer in the unconsolidated Cenozoic alluvium-a case study. Arabian Journal of Geosciences, vol. 7, no. 6. pp. 2139-2149.

Cui, X., Miao, X., Wang, J., Yang, S., Liu, H., Song, Y., Liu, H., and Hu, X. 2000. Improved prediction of differential subsidence caused by underground mining: International Journal of Rock Mechanics and Mining Sciences, vol. 37. pp. 615-627.

Cundall, P.A. 1988. Formulation of a three-dimensional distinct element model Part I. A scheme to detect and represent contacts in a system composed of many polyhedral blocks. International Journal of Rock Mechanics and Mining Sciences, vol. 25, no. 3. pp. 107-116.

Cundall, P.A. 1990. Numerical modeling of jointed and faulted rock. Proceedings of the International Conference on Mechanics of Jointed and Faulted Rock, Vienna, Austria. Rossmanith, H. P. (ed.). AA Balkema, Rotterdam. pp. 11-18.

Gui, H.R., Zhou, Q.F., Liao, D.S., KAng, Q.G., and Fan, Z.Y. 1997. Prediciton of maximum height of the fractured zone by stressing method for sub-level caving mining. Journal of China Coal Society, vol. 22, no. 4. pp. 375-379 (in Chinese with English abstract).

Guo, H., AdHIKARY, D.P., and CRAIG, M.S. 2008. Simulation of mine water inflow and gas emission during longwall mining. Rock Mechanics and Rock Engineering, vol. 42, no. 1. pp. 25-51.

Hart, R., Cundall, P.A., and Lemos, J. 1988. Formulation of a threedimensional distinct element model Part II. Mechanical calculations for motion and interaction of a system composed of many polyhedral blocks. International Journal of Rock Mechanics and Mining Sciences, vol. 25, no. 3. pp. 117-125.

HE, G., YAnG, L., Ling, G., JiA, C., and Hong, D. 1991. Mining Subsidence Science. University of Mining and Technology Press, Xuzhou, China (in Chinese).

HuAng, Z.A., Tong, H.F., Zhang, Y.H., LI, S.B., NI, W., Song, J.G., and XING, Y. 2006. Dividing guideline and emulating determination of 'three zones' of the depressing zones overlying a goaf. Journal of University of Science and Technology Beijing, vol. 28, no. 7. pp. 609-612 (in Chinese with English abstract).

INDUSTRY, S.B.O.C. 2004, The regulation of leaving coal pillar and mining coal of holding under the buildings, water bodies, railways and the main roadway. Coal Industry Press, Beijing (in Chinese).

Islam, M.R., Hayashi, D., and Kamruzzaman, A.B.M. 2009. Finite element modeling of stress distributions and problems for multi-slice longwall mining in Bangladesh, with special reference to the Barapukuria coal mine: International Journal of Coal Geology, vol. 78, no. 2. pp. 91-109.

ITASCA Consulting Group. 2004. UDEC Manual. Minneapolis, Minnesota, USA.

JING, L. 2003. A review of techniques, advances and outstanding issues in numerical modelling for rock mechanics and rock engineering: International Journal of Rock Mechanics and Mining Sciences, vol. 40, no. 3. pp. 283-353. 


\section{Impact of thick alluvial soil on a fractured water-conducting zone}

KIRSTEN, H.A.D. and STACEY, T.R. 1989. Stress-displacement behaviour of the fractured rock around a deep tabular stope of limited span. Journal of the South African Institute of Mining and Metallurgy, vol. 89, no. 2. pp. $47-58$.

KRATzsch, H. 1983. Mining Subsidence Engineering. Springer-Verlag, Berlin.

LI, G. and ZHou, W. 2005. Impact of karst water on coal mining in North China. Environmental Geology, vol. 49, no. 3. pp. 449-457.

Li, T., Mei, T., Sun, X., Lv, Y., Sheng, J., and CAI, M. 2013. A study on a waterinrush incident at Laohutai coalmine. International Journal of Rock Mechanics and Mining Sciences, vol. 59. pp. 151-159.

Liv, J.J. 2008. Analysis and calculation on parameters of stress distribution of the front coal mining face. Journal of China Coal Society, vol. 33, no. 8. pp. 745-747 (in Chinese with English abstract).

LIU, Y., DAI, H., and JiAng, Y. 2012. Model test for mining-induced movement law of rock and soil mass under thick unconsolidated layers. Journal of Mining and Safety Engineering, vol. 29, no. 5. pp. 268-272 (in Chinese with English abstract).

Lu, Y. and WANG, L. 2015. Numerical simulation of mining-induced fracture evolution and water flow in coal seam floor above a confined aquifer. Computers and Geotechnics, vol. 67. pp. 157-171.

Luo, J. 1982. Determination of the interface of fractured water-conducting zone by drilling boreholes. Coal Geology and Exploration, no. 1. pp. 53-56 (in Chinese).

Ma, L., Zhang, D., Sun, G., CuI, T., and Zhou, T. 2013. Thick alluvium fullmechanized caving mining with large mining height face roof control mechanism and practice. Journal of China Coal Society, vol. 38, no. 2. pp. 199-203 (in Chinese with English abstract).

Miao, X., Cui, X., WAng, J.AA., and Xu, J. 2011. The height of fractured waterconducting zone in undermined rock strata. Engineering Geology, vol. 120 , no. 1-4. pp. 32-39.

Moarefvand, P. and VerdeL, T. 2008. The probabilistic distinct element method. International Journal for Numerical and Analytical Methods in Geomechanics, vol. 32, no. 5. pp. 559-577.

Peng, S. and Zhang, J. 2007. Engineering Geology for Underground Rocks. Springer, New York.

PENG, S.S. 1992. Surface Subsidence Engineering. Society for Mining Metallurgy and Exploration, Littleton, $\mathrm{CO}$.

QIAN, M.G., Miao, X.X., Xu, J.L., and MAo, X.B. 2003. Study of Key Strata Theory in Ground Control. China University of Mining and Technology Press, Xuzhou (in Chinese)

QIAN, M.G. 1982. A study of the behavior of overlying strata in longwall mining and its application to strata control. Proceedings of the Symposium on Strata Mechanics, Newcastle-on-Tyne, 5-7 April 1982. Elsevier Scientific Publishing, New York. pp. 13-17.

QIAN, M.G., SHI, P.W., and Xu, J.L. 2010. Mining Pressure and Strata Control. China University of Mining and Technology Press, Xuzhou (in Chinese).

Teng, Y.H. 2011. Development features and max height calculation of water conducted fractured zone caused by fully mechanized top coal caving mining. Coal Science and Technology, vol. 39, no. 4. pp. 118-120 (in Chinese with English abstract).

Tu, M. 2004. Study on the growth height of separation fracture of mining rock in Panxie area. Journal of China Coal Society, vol. 29, no. 6. pp. 641-645 (in Chinese with English abstract).

WANG, G.C. 1999. Preliminary approach of increasing the upper limit of extraction in Pan-xie mining area. Journal of Huainan Institute of Technology, vol. 19, no. 1. pp. 40-44 (in Chinese)

Wang, J.A. and Park, H.D. 2003. Coal mining above a confined aquifer. International Journal of Rock Mechanics and Mining Sciences, vol. 40, no. 4. pp. 537-551.

Wang, Y., Deng, K., Wu, K., and Guo, G. 2003. On the dynamic mechanics model of mining subsidence. Chinese Journal of Rock Mechanics and
Engineering, vol. 22, no. 3. pp. 352-357 (in Chinese with English abstract).

Wu, L., JiAng, Z., ChEng, W., Zuo, X., Lv, D., and YAo, Y. 2011. Major accident analysis and prevention of coal mines in China from the year of 1949 to 2009. Mining Science and Technology (China), vol. 21, no. 5. pp. 693-699.

Wu, Q., Liu, Y., Luo, L., Liu, S., Sun, W., and Zeng, Y. 2015. Quantitative evaluation and prediction of water inrush vulnerability from aquifers overlying coal seams in Donghuantuo Coal Mine, China. Environmental Earth Sciences, vol. 74, no. 2. pp. 1429-1437.

WU, X., Wang, X.G., Duan, Q.W., Yu, Q.C., Yang, J., and Sun, Y.D. 2008. Numerical modeling about developing high of water flowing fractured zone. Journal of China Coal Society, vol. 33, no. 6. pp. 609-612 (in Chinese with English abstract).

Xu, G., Xu, J.L., Lu, W.Y., and FAn, D.Y. 2010. Lateral boundary prediction of water conducting fracture formed in roof and its application. Chinese Journal of Geotechnical Engineering, vol. 32, no. 5. pp. 724-730 (in Chinese with English abstract).

Xu, Y. and ZHANG, Y. 2002. Deformation characteristics of thick unconsolidated layers due to mining by UDEC. Journal of China Coal Society, vol. 27, no. 3. pp. 268-272 (in Chinese with English abstract).

YANG, B. and GAO, D. 1982. Determination of top boundary of fractured waterflowing zone by drilling simple hydrogeological method. Mine Surveying, no. 1. pp. 53-56 (in Chinese).

Yang, T.H., Liv, J., Zhu, W.C., Elsworth, D., Tham, L.G., and Tang, C.A. 2007. A coupled flow-stress-damage model for groundwater outbursts from an underlying aquifer into mining excavations. International Journal of Rock Mechanics and Mining Sciences, vol. 44, no. 1. pp. 87-97.

YANG, Z.Z., WANG, J.C., and Lu, F.W. 1994, Technical counter measures for coal mining under buildings, water-bodies and railways in Huainan coal mines. Journal of China Coal Society, vol. 19, no. 1. pp. 5-14.

YuAN, L. and Wu, K. 2003. Theoretical Research and Technology practice on Mining under the Huaihe River Embankment. China University of Mining and Technology Press, Xuzhou (in Chinese).

YuAn, L., Wu, K., Du, G., and TAN, Z. 2001. monitoring of Huaihe Dike deformation caused by mining. Journal of China University of Mining and Technology, vol. 11, no. 1. pp. 14-19.

YuAN, R., LI, Y., and JiAo, Z. 2015. Numerical analysis of water inrush from working face floor during mining. Procedia Engineering, vol. 102. pp. 1857-1866.

YuAN, W.B. and CHEN, J. 1986. Analysis of plastic zone and loose zone around opending in softening rockmass. Journal of China Coal Society, no. 3. pp. 78-86 (in Chinese with English abstract).

ZHANG, J. 2005. Investigations of water inrushes from aquifers under coal seams. International Journal of Rock Mechanics and Mining Sciences, vol. 42, no. 3. pp. 350-360.

ZHANG, J. and SHEN, B. 2004. Coal mining under aquifers in China: a case study. International Journal of Rock Mechanics and Mining Sciences, vol. 41, Ino. 4. pp. 629-639.

Zhang, J.C. and Peng, S.P. 2005. Water inrush and environmental impact of shallow seam mining. Environmental Geology, vol. 48, no. 8. pp. 1068-1076.

Zhang, W.Y., Wang, W.G., Peng, W.D., Feng, Z.H., and Shun, K.S. 2002. The coal mining practice of reducing waterproof coal pillars in Panxie Mining Area. Journal of China Coal Society, vol. 27, no. 2. pp. 128-133 (in Chinese with English abstract).

Zноч, D.W. 2014. The synergy mechanism between rock mass and soil in mining subsidence and its prediciton. $\mathrm{PhD}$ thesis, China University of Mining and Technology (in Chinese with English abstract).

ZHou, D.W., Wu, K., CHeNG, G.L., and LI, L. 2015. Mechanism of mining subsidence in coal mining area with thick alluvium soil in China. Arabian Journal of Geosciences, vol. 8, no. 4. pp. 1855-1867. 